\title{
Relay Translation On Dayak Ngaju, Indonesian, And English: Analysis On Cultural Terms In Dayak Mythology "Tatum"
}

\author{
Lida Karyani \\ \{lidakaryani@gmail.com\} \\ Balai Bahasa Provinsi Kalimantan Tengah, Jalan Tingang km. 3,5, Palangka Raya
}

\begin{abstract}
The research described the relay translation of Dayak oral tradition from Dayak Ngaju to Indonesian and from Indonesian to English. The research used a descriptive qualitative method with content analysis and FGD for data collection and interviews for data validation. It attempted to explain the translation techniques in translating specific terms from Dayak Ngaju (L1) to Indonesian (L2) and English (L3). The data were 22 cultural terms in L1-L2 translation. The translation techniques applied were pure borrowing, established equivalent, generalization, description, pure borrowing + addition, established equivalent + pure borrowing, and discursive creation + established equivalent + description. Then, the data in L2-L3 translation were 12 cultural terms. The translation techniques applied were pure borrowing, established equivalent, generalization + pure borrowing, pure borrowing + addition, and established equivalent + pure borrowing + established equivalent. The translator preferred to maintain the originality of cultural terms in L2- L3 translation.
\end{abstract}

Keywords: relay translation; translation techniques; Dayak cultural terms

\section{Introduction}

Dayak Ngaju is an indigenous tribe among other Dayak tribes in Kalimantan (Borneo) who lives along the rivers of Kahayan, Kapuas, Katingan, and Barito [1]. The Dayaks used to live in oral culture or oral tradition and Dayak Ngaju is the lingua franca among Dayaks in Central Kalimantan [2]. Masinambouw in [3] mentioned language and culture are two systems that are attached to human. In addition, culture is the way of life; expressing it in a community is typical, and it is expressed through language [4]. Therefore, each culture certainly has specific terms to describe the life and surrounding nature, including the Dayaks. In translation study, these specific terms for certain things in a particular culture can become challenging [5]. In other words, the challenge for translator is to translate cultural terms to target languages in different cultures. After all, humans can recognize other cultures beyond their communities through translation. As Newmark in [5]) said translation introduces a culture to another.

Translation has a significant role in the process of multicultural communication and has been studied in many philological works [6]. Translating Dayak folklores to Indonesian and foreign languages is different from translating general texts. The texts contain specific cultural 
terms. One of Central Kalimantan folklores, having transcribed by Dayak culture expert in Central Kalimantan (the late AF Nahan), is 'tatum' [7]. Tatum ( $n$ ) or natum $(v)$ is a mythological story about the origin of the Dayak tribe sung like a wailing song [2]. It was transcribed into Dayak Ngaju, translated into Indonesian, and retranslated into English. Interestingly, Tatum came through some translation processes in terms of Dayak NgajuIndonesian and Indonesian-English. The translation field is called a relay translation. A source text is translated into a target text, and the translation text is translated into a different target text. It is confidential that existing literature in the world, such as fiction, is often as the result of relay translation. For example, The Brother Grimm by Hans Christian Andersen was translated from Dutch to German and retranslated from German to English. Moreover, the English version was then translated into Japanese and Mandarin. Another example is The Arabian Nights, translated from Arabic to France and retranslated from France to Dutch. The holy text, likes Bible, was translated from source texts (Hebrew and Greek) to English, and retranslated into Indonesian and then retranslated into local languages in Indonesia. These processes of translation are so-called relay translation. According to [8] it is not a text's double, yet it is a further iteration of a text.

Translation experts use different terms on relay translation. It is generally called indirect translation and relay translation. Shuttleworth and Cowie in [9] proposed indirect translation as a text translation indirectly translated from the original text through a medium in another language. Besides, [10] mentioned that it is a translation from a translation. Moreover, [11] defined it as a translation entailing an intermediate translation and therefore entailing three languages. These experts reinforced the procedure of indirect translation through an intermediate translation or mediated translation $(M T)$ that becomes a medium between source text (ST) and target text (TT). Despite that, [11] emphasized that a MT is not addressed to authentic audiences but as a medium or bridge between ST and TT when a translators do not master the language of original texts (ST). In reverse, the relay translation is originally from a translation that has its audiences [11]. The first translation has its audiences in related languages and then becomes the source text for the next translation. It entails at least three languages (L1, L2, L3). The source language is named L1, the first target language or first translation is called L2, and the second target language is L3. When the first translation (L2) is chosen to be the source text for the next translation, it becomes a relay in accordance with the source of data. The translation of Tatum is a relay translation since it is translated from the source language, Dayak Ngaju (L1), to the first target language, Indonesian (L2), for its target audience (Indonesian readers). Then the translator used the translation (L2) as the source text to be translated into English (L3) for its target audience (English readers).

Several translation pieces of research related to cultural terms have been carried out. [12] in "Relay Translation of Feminism in China: An Intralingual Case" investigated the translation of monolog drama, The Vagina Monologues (Ensler 1998). It is claimed that many terms in the source text are considered taboo in Chinese culture. Another research on "Relay Translation of Javanese Prohibitions: Techniques and Quality" has been discussed by [9] to reveal the translation of Pitutur Luhur Jawa with a lot of cultural expressions. It was translated from Javanese to Indonesian and retranslated from Indonesian to English. The revelation of the Javanese cultural concept into Indonesian and English was considered difficult since it involved three different cultures. Besides, [5], in The reconstruction of the image of Javanese as an old language through an English translation of Javanese cultural terms in Indonesian novel 'Gadis Kretek'" showed the research on the translation of Javanese cultural terms into English. It found that the translation of Javanese cultural terms has some 
levels concerning social status and contexts in Java (Javanese speech levels). It becomes challenging for the translator since the English cultural system has no speech levels.

$\mathrm{Yu}$ revealed that the translation of The Vagina Monologues in Mandarin tends to use adaptation and naturalization techniques so that the translation becomes acceptable for Mandarin readers. Their acceptance is regarded as more necessary than its accuracy. In addition, both Hardiyanti et al. and Sujatmika et al. explored the translation techniques of Javanese cultural expression and their impact on the quality. Even so, their researches are not associated with translation shift.

While $\mathrm{Yu}$ and Hardiyanti were discussed Mandarin and Javanese languages, the present one preferred to investigate Dayak Ngaju as the source language. Dayak Ngaju language is principally from the oral culture because there are no ancient texts or cultural texts in written forms. A strong oral tradition is designated by the absence of written texts from the past Dayak tribe [13]. The Dayak tribe could not recognize letters but used specific symbols to communicate in a particular situation [2]. On the contrary, Javanese and Mandarin have their scripts. The Dayak cultural terms being investigated focused on material cultures, referring to the categorization of cultural terms proposed by Newmark. [4] mentioned that material cultures/artifacts always become characteristics of a culture. They include typical foods, drinks, clothes, houses, means of transportation, and means of communication. The present research analyzed the translation techniques of Dayak cultural terms from L1-L2 and L2-L2 and the translation shifts from the source languages to the target languages. Since the data dealt with terms, the researcher pointed out the theory of [14] to identify the translation techniques. Molina and Albir in [15] pointed out that translation techniques is the procedure to analyze and classify how translation equivalence work. They were identified in the microlevel from words to clauses by comparing source texts and translations (L1-L2 and L2-L3). The translation techniques are adaptation, amplification, borrowing, calque, compensation, description, discursive creation, established equivalent, generalization, linguistic amplification, linguistic compression, literal translation, modulation, particularization, reduction, substitution, transposition, and variation. After that, the translation shifts were recognized on the translation (L1-L2 and L2-L3). Whether the Dayak cultural terms were maintained or shifted into general terms was reflected as a direct impact of translation techniques.

\section{Method}

The research employed a qualitative descriptive method to reveal the phenomenon of relay translation on Dayak cultural terms from Dayak Ngaju to English through Indonesian. It discussed translation techniques and translation shifts in terms of forms of the terms due to translation techniques usage.

The data were obtained from Dayak oral tradition, namely Tatum [7]. Tatum deals with a myth of the origin of the Dayak tribe performed as a wailing song. As an oral tradition, Tatum was transcribed and published in Dayak Ngaju, then translated into Indonesian and English (through Indonesian). The data were in terms of words and phrases. In line with [16], he proposed that data are words, sentences, or pictures containing meaning to manifest a deep understanding in contrast to numbers. Location, needs to fulfil three basic elements, including participants, setting, and events [17]. These elements were fulfilled in this folklore and able to become the elements of the research location. 
Content analysis, interview, and focus group discussion (FGD) were techniques for data collection. Content analysis was used since the object of research was linguistic data taken from a document (Krippendorf in [18]). The interview involved three experts in language and Dayak culture to validated the data. The researcher and two raters carried out FGD to identify the translation techniques.

\section{Result and Discussions}

\subsection{Results}

The research included three languages, Dayak Ngaju (L1) as the source language, Indonesian (L2) as the first target language in which, then, become the source language for the next translation (mediated translation/relay), and English (L3) as the next translation or second target language. It found 22 data related to Dayak material cultural terms on the L1-L2 translation. They were translated using single, couplet, and triplet techniques. The couplet and triplet techniques were signified by plus mark $(+)$ (see table 1). The techniques were pure borrowing, established equivalent, adaptation, generalization, description, pure borrowing + addition, established equivalent + pure borrowing, dan discursive creation + established equivalent + description. The frequency of these techniques is reflected in table 1 .

Table 1. Frequency of translation techniques usage on L1-L2

\begin{tabular}{lcc}
\multicolumn{3}{c}{ Table 1. Frequency of translation techniques usage on L1-L2 } \\
\hline \multicolumn{1}{c}{ Translation Techniques } & Data & Frequency \\
\hline Pure borrowing & 8 & 8 \\
Established equivalent & 3 & 3 \\
Adaptation & 3 & 3 \\
Pure borrowing + Addition & 3 & 3 \\
Generalization & 2 & 2 \\
Description & 1 & 1 \\
Discursive creation + Established Equivalent + Description & 1 & 1 \\
Established equivalent + Pure borrowing & 1 & 1 \\
\hline Total & 22 & 22 \\
\hline
\end{tabular}

\section{a) Pure Borrowing}

\section{L1: betang $\rightarrow$ L2: betang}

Betang is a traditional house of the Dayak tribe in Central Kalimantan in the past. It is a rumah panggung (stilt house) from ironwoods. It has an elongated shape of utmostly 150 meters with a width of 10-30 meters. It can accommodate tens of families. In example 1 , the translator used pure borrowing to translate betang from L1 to L2. It is usually selected when the translator does not find an equivalent term in the target. It deals with borrowing a term from a source language without changing a form of a word or term into a target one.

\section{b) Established Equivalent}

\section{L1: lanting $\rightarrow$ L2: rakit}

Lanting is a means of river transportation from round woods constructed and used by the Dayak tribe in the past. In example 2, the translator used an established equivalent to transfer 
the meaning of lanting. It refers to a usual or common equivalent used and existing in the dictionary (Kamus Besar Bahasa Indonesia or the Great Indonesian Dictionary).

\section{c) Adaptation}

\section{L1: garantung $\rightarrow$ L2: gong.}

Garantung is a traditional music instrument of the Dayak tribe. It looks like a traditional Javanese music instrument, gong, that is more acknowledged in Indonesian culture. The translator used gong for garantung, attributed to the adaptation technique. It is indicated as changing a cultural term in a source language with a cultural term in a target language with similarities and/or being familiar with target audiences.

\section{d) Generalization}

\section{L1: lamin $\rightarrow$ L2: rumah panjang.}

Lamin is a traditional house of the Dayak tribe in East Kalimantan. It has a big, elongated, and story shape. Lots of families inhabit it. The translator generally translated lamin in terms of shape, or so-called as generalization technique. It technically refers to use a more general term in a target language while a source language uses a specific term.

\section{e) Description}

L1: damek baipu $\rightarrow$ L2: anak sumpitan beracun

Damek is anak sipet (sumpit), referring to a chopstick, a Dayak traditional weapon containing poison to hunt and battle in the past. The term damek baipu has no equivalent in Indonesian. Due to that reason, the translator used the description technique by using its function. It is represented by changing a term or expression with a description of its shape and/or function.

\section{f) Pure Borrowing + Addition}

\section{L1: lunju $\rightarrow$ L2: lunju (tombak)}

Lunju is a Dayak traditional weapon in terms of spear used to hunt. The translator used pure borrowing techniques using the original term of the source language in the target (lanju $\rightarrow$ lanju). Using the addition technique, the translator also added additional information regarding the meaning of lanju in the 'brackets.' It adds a detail or information not existing or mentioned in the source language.

\section{g) Established Equivalent + Pure Borrowing}

\section{L1: gita lepu $\rightarrow$ L2: getah lepu}

Gita lepu is a sap of kind of palm tree. The translator used an established equivalent for gita into getah (sap). The pure borrowing technique was also used to borrow the original term of lepu (lepu $\rightarrow$ lepu).

\section{h) Discursive Creation + Established Equivalent + Description}

L1: palangka bulau $\rightarrow$ L2: wadah emas (sekaligus merupakan kendaraan angkasa) 
Palangka is an outrigger boat with its tip shaped into the head of a hornbill bird and another tip shaped into its tail. The term palangka was translated using discursive creation (palangka $\rightarrow$ wadah referring to a container). This technique is usually used in translating titles of films. It shows a temporary equivalent in a target language that is occasionally out of context. In addition, the term bulau was translated using established equivalent (bulau $\rightarrow$ emas dealing with gold). Moreover, a description technique was used (see in the brackets) to clarify the meaning of palangka. Thus, there were three techniques to transfer the meaning of palangka bulau.

In the intermediate translation (L2-L3), Indonesian (L2) becomes the source language for English (L3) as the target language. The study found 12 terms of Dayak material culture. It utilized pure borrowing, pure borrowing + addition, dan generalization + pure borrowing. The frequency of translation technique usage is shown in table 2.

Table 2. Frequency of translation techniques usage on L2-L3

\begin{tabular}{lcc}
\hline \multicolumn{1}{c}{ Translation techniques } & Data & Frequency \\
\hline Pure borrowing & 9 & 9 \\
Pure borrowing + addition & 2 & 2 \\
Generalization + pure borrowing & 1 & 1 \\
\hline Total & 12 & 12 \\
\hline
\end{tabular}

\section{a) Pure Borrowing}

\section{L2: totok bakaka $\rightarrow$ L3: totok bakaka}

The term totok bakaka consists of two words: totok (beak) and bakaka (kingfisher). This term was used to name the sign language of the Dayak tribe in the past. It was borrowed in L3 without changing its form, as indicated as a pure borrowing technique. This technique borrows a word or expression from a source language without changing its form in a target language.

\section{b) Generalization + Pure Borrowing}

\section{L2: betang $\rightarrow$ L3: long house (betang)}

The term betang was translated into longhouse by generalizing the specific term into the general one. It refers to the generalization technique. It is usually used to translate a term in which a particular equivalent is not recognized in a target language.

\section{c) Pure Borrowing + Addition}

L2: lunju bunu $\rightarrow$ L3: lunju bunu (killing spear)

Lunju is a Dayak traditional weapon in terms of the spear used to battle in the past. Lunju buru was translated into the exact term using pure borrowing technique and added by the additional information in the brackets, 'killing spear,' using addition technique. The addition was used by adding a detail or information not indicated in the target language. It was conducted to help the translator to deliver the message or to make the target audience understand.

The research indicated several Dayak material cultural terms having shifted. The shift related to a condition, the specific term in the source language changed into the general one in 
the target. It occurs on the L1-L2 translation of as many as 10 data. As a result, in the L2-L3 translation, the data decreased, as many as 12 data. The data of translation shift is reflected in the following table 3 .

Table 3. Shift of Dayak material cultural terms on L1-L2

\begin{tabular}{|c|c|c|}
\hline L1 (Dayak Ngaju) & L2 (Indonesian) & Translation Techniques \\
\hline palangka bulau & $\begin{array}{l}\text { wadah emas (sekaligus } \\
\text { kendaraan angkasa) }\end{array}$ & $\begin{array}{l}\text { Discursive creation }+ \text { Established } \\
\text { equivalent }+ \text { Description }\end{array}$ \\
\hline Lanting & Rakit & Established equivalent \\
\hline Garantung & Gong & Adaptation \\
\hline Kangkanung & Genong & Adaptation \\
\hline Gandang & Gendang & Adaptation \\
\hline penyang & Azimat & Generalization \\
\hline lamin & rumah panjang & Generalization \\
\hline damek baipu & anak sumpitan beracun & Description \\
\hline sipet & sumpit & Established equivalent \\
\hline mangkuk bahandang & mangkok merah & Established equivalent \\
\hline
\end{tabular}

Table 3 showed that specific terms in Dayak culture have no longer specified in the translation version. The shifts occurred due to the use of translation techniques. The techniques changing the Dayak material cultural terms into the general ones were established equivalent, generalization, description, and discursive creation + established equivalent + description. Meanwhile, the adaptation technique changed the Dayak material cultural terms into the specific ones in another culture (Javanese).

\subsection{Discussion}

In translating the Tatum, the translator used a single technique and a couplet and triplet. The translator probably used this strategy to solve the translation problem by combining two or more techniques (Newmark in [14]). In the L1-L2 translation, the translator used single techniques in terms of pure borrowing, established equivalent, adaptation, generalization, and description. For couplet techniques, the translator uses pure borrowing + addition and pure borrowing + established equivalent. And for the triplet technique, that is discursive creation + established equivalent + description.

In the L1-L2 translation, pure borrowing was the most frequent technique as many as eight times. It was used to transfer the meaning of totok bakaka, ewah, patinju, betang, lalang pantu, halamaung, batu bulan, and duhung. It refers to borrowing a term from a source language without changing its form into a target language. It is usually used due to the absence of a specific equivalent in a target language. The absence of equivalent terms tends to be found due to different cultural concepts between L1 and L2 so that L2 has no vocabulary to provide or represent the cultural concept in L1.

The second technique was established equivalent. It was used three times to transfer the meaning of mangkuk bahandang, lanting, and sipet. Mangkuk bahandang was translated into mangkok merah, lanting into rakit, and sipet into sumpit. This technique allows the translator to use a common or general term usually used and existing in the dictionary.

The third technique was adaptation. It was found as many as 3 in transferring the meaning of garantung, kangkanung, and gandang. Garantung was translated into gong (a Javanese traditional music instrument). Kangkanung into kenong (a Javanese traditional music instrument). Gandang was translated into gendang (a music instrument with a long log, in 
which there is a hollow space and one of the holes or both is covered by skin). This technique lets the translator change a cultural element in a source language into a cultural element in a target language with similarities and/or be familiar with target audiences.

The fourth technique was a generalization. It was found as many as 2 in translating penyang and lamin. Penyang was translated into azimat (stuff considered to have supernatural powers and to be able to protect their owners, and lamin into rumah panjang (long house). The generalization technique was used by transferring a more general term in the target language in which it has a specific term in a source language.

The fifth technique was the description. It was used once to translate damek baipu. Description technique deals with changing a term or expression with a description of its shape or function. Damek baipu was described as anak sumpit beracun.

The sixth and seventh techniques were couplet, namely pure borrowing + addition and established equivalent and pure borrowing. Pure borrowing + addition was used three times to translate lunju, mandau, and lunju bunu. By using these techniques, the translator transfered the meaning of lunju $\rightarrow$ lunju (tombak), mandau $\rightarrow$ mandau (senjata tradisional khas Dayak, sejenis parang), and lunju bunu $\rightarrow$ lunju bunu (tombak pembunuh. The addition technique was used to add a detail or information not recognized or mentioned in a source language. In this context, the additional information was included in the 'brackets.' Besides, established equivalent + pure borrowing was used once on translating gita lepu into getah lepu.

The last technique was triplet (discursive creation + established equivalent + description) applied once to translate palangka bulau. The term palangka was translated into wadah using the discursive creation technique. It usually shows a temporary equivalent in a target language that is occasionally out of context. Next, the term bulau was translated using established equivalent (bulau $\rightarrow$ emas). Moreover, the description technique was also used to clarify the meaning of palangka (a meaning placed in the brackets). Thus, there was three-technique used at once in transferring the meaning of palangka bulau.

In the L2-L3 translation, the most frequent technique was pure borrowing, used nine times. The terms totok bakaka, lunju, ewah, patinju, lalang pantu, halamaung, lepu, mandau, and duhung were maintained by the translator as pure borrowing techniques. Secondly, the couplet of pure borrowing + addition was also used in translating lunju bunu $\rightarrow$ lunju bunu (killing spear) and batu bulan $\rightarrow$ batu bulan (moonstone). Lastly, generalization + pure borrowing was also used to transfer the betang $\rightarrow$ long house (betang).

In a translation text, a shift possibly occurs concerning specific terms. A target language has no vocabulary or terms to provide or represent a cultural concept in a source language. Accordingly, a translator will choose an appropriate way or translation technique to convey this cultural concept. In the translation of Tatum (L1-L2), the translators frequently used established equivalent in transferring the meaning of Dayak material cultural terms. Some of them can be translated using this technique since the meaning containing in the terms is well conveyed. Otherwise, the use of this technique changed the specific terms into the general ones, for instance, mangkuk bahandang $\rightarrow$ mangkok merah, sipet $\rightarrow$ sumpit, and lanting $\rightarrow$ rakit.

Similarly, the use of generalization and description causes the absence of cultural concepts in the target language. Lamin referring to a long stilt house was generalized into 'rumah panjang' (a long house), resulting in the absence of typical and specific characteristics. Meanwhile, adaptation technique was used to make the translation more acceptable or appropriate to the target culture. Still, its usage resulted in changing the Dayak material cultural terms into the target cultural terms (garantung $\rightarrow$ gong, kangkanung $\rightarrow$ kenong, gandang $\rightarrow$ gendang). Moreover, the combination of discursive creation + established 
equivalent + description shifted the Dayak material cultural terms into the unspecific terms. These techniques caused the nature of the source culture uncertain or even lost in the translation. Some of the terms in the L1-L2 translation were not maintained as the Dayak material cultural terms. Conversely, in the L2-L3 translation, the terms tend to be maintained as the Dayak material cultural terms in the target language (English) with the employment of pure borrowing, pure borrowing + addition, and generalization + pure borrowing.

The research indicated that the most frequent translation technique in the Tatum translation (L1-L2 and L2-L3) was pure borrowing. It was also found the combination between pure borrowing and addition. Employing pure borrowing and addition techniques, the translator borrowed the terms in the source language and added information related to the meaning of the terms based on target audiences' understanding of unfamiliar terms. It was claimed that the combination of these techniques was considered to be appropriate in translating the Dayak material cultural terms. The terms remain specific in the target language and well-defined to the target audiences through additional information. Pure borrowing and pure borrowing + addition will introduce the source culture (Dayak Ngaju) to the target culture (Indonesian and English).

The result of this research contained some differences from the previous. Yu discovered adaptation and naturalization as the most frequent techniques on translating The Vagina Monologue to make the translation acceptable in the target culture (Chinese). These techniques overcome the struggle of translating taboo terms in Chinese culture. In contrast, Hardiyanti revealed generalization and pure borrowing as the most selected technique to transfer the Javanese cultural terms into English. Furthermore, Sujatmiko showed established equivalent as the dominant technique used on translating the Javanese cultural expression into Indonesian and English.

\section{Conclusion}

In the L1-L2 translation, the research identified some techniques for transferring the Dayak cultural terms, including pure borrowing, established equivalent, adaptation, generalization, description, pure borrowing + addition, established equivalent + pure borrowing, and discursive creation + established equivalent + description. In the L2-L3 translation, the research reflected the application of pure borrowing, pure borrowing + addition, and generalization + pure borrowing. Dayak material cultural terms shift due to the employment of established equivalent, generalization, description, adaptation, and discursive creation + established equivalent + description.

Translating cultural texts offers a significant challenge in accordance with specific terms. This challenge includes finding equivalent terms and meanings in target language. The complication of cultural differences between source and target languages is more challenging than language structural differences (Nida in [5]. A translator should have a cross cultural understanding in translating cultural texts. A translator could conduct a cultural observations and interviews with cultural experts before doing a translation work [19]. Thus in the field of translation, translator competence is significant in order to produce a good quality of translation [20]. A translator of cultural texts is also supposed to be aware that cultural terms have to be maintained to introduce the terms in target languages.

The present research indicated that some Dayak cultural terms regarding words and phrases were translated using more than one technique. The application of some techniques (couplet or triplet) was to obtain the meaning equivalents in the target language. Due to that 
fact, the research suggests translators of cultural texts use the couplet technique, pure borrowing + addition, on translating cultural terms. By using the pure borrowing technique, cultural terms were initially transferred in target languages so that target audiences recognize them. Additionally, the addition technique's use clarifies the meaning by adding some information of the meaning of terms. Moreover, the translation text will contain specific, unique, and exotic cultural terms concerning pure borrowing techniques. In line with Gorlee in [11], a relay translation will produce a translation containing a combination of exotic languages. It was portrayed in the L2 text as a relay for L3. The L2 text (Indonesian) contains Dayak cultural terms translated into the English text (L3).

\section{References}

[1] K. Usop, Pemerian Morfologi Bahasa Dayak Ngaju. Pusat Pembinaan dan Pengembangan Bahasa, Departemen Pendidikan dan Kebudayaan, 1976.

[2] T. Riwut and S. Mantikei, Maneser Panatau Tatu Hiang, Menyelami Kekayaan Leluhur. Pusaka Lima, 2012.

[3] A. Chaer and L. Agustina, Sosiolingusitik. Jakarta: Rineka Cipta, 2014.

[4] P. Newmark, A Textbook of Translation. Hertfordshire: Prentice Hall International Ltd., 1988.

[5] D. Hardiyanti, Y. Nugraheni, M. Nababan, and R. Santosa, "the Reconstruction of the Image of Javanese As an Old Language Through an English Translation of Javanese Cultural Terms in Indonesian Novel 'Gadis Kretek,"' Indones. J. Appl. Linguist., vol. 11, no. 1, pp. 30-38, 2021, doi: 10.17509/ijal.v11i1.34670.

[6] A. G. Stroilova and N. M. Dmitriev, "Intermediary Translation in Russian and English Literary Relations: Analysis of 'Night Thoughts' by E. Young in Russian Translations," Procedia - Soc. Behav. Sci., vol. 236, no. December 2015, pp. 131-138, 2016, doi: 10.1016/j.sbspro.2016.12.051.

[7] A. F. Nahan and D. D. Rampai, The Ot Danum From Tumbang Miri Until Tumbang Rungan. Palangka Raya: WWF-Indonesia, Pemerintah Provinsi Kalimantan Tengah, 2010.

[8] K. Washbourne, "Nonlinear Narratives: Paths of Indirect and Relay Translation," Meta, vol. 58, no. 3, pp. 607-625, 2014, doi: 10.7202/1025054ar.

[9] S. Sujatmiko, M. R. Nababan, D. Djatmika, and S. Supana, "Relay Translation of Traditional Javanese Advices From Butir-ButirBudaya Jawa's Book," 2020, doi: 10.4108/eai.8-9-2020.2301439.

[10] H. Pięta, "Indirect translation: Main trends in practice and research," Slovo.ru Balt. Accent, vol. 10, no. 1, pp. 21-36, 2019, doi: 10.5922/2225-5346-2019-1-2.

[11] C. Dollerup, "Relay in Translation," Cross-linguistic Interact. Transl. Contrastive Cogn. Stud., 2014.

[12] Z. Yu, "Relay translation of feminism in China: An intralingual case," J. Transl. Stud., vol. 1, p. 2, 2017.

[13] S. K. Wijanarti, T., Sudardi, B., Wijaya, M., \& Habsari, "The Oral Tradition of Sansana Bandar of Dayak Ngaju in Kapuas Watershed of Central Kalimantan," Aksara, vol. 32(2), no. 2, p. 235-246., 2020, doi: 10.29255/aksara.v32ii1.513.235--246.

[14] L. Molina and A. H. Albir, "Translation techniques revisited: A dynamic and functionalist approach," Meta, vol. 47, no. 4, pp. 498-512, 2002, doi: 
10.7202/008033ar.

[15] D. Nugrahani, M. R. Nababan, R. Santosa, and Djatmika, "Translating Javanese Culture Expressions in a Novel: Techniques and Quality," J. Soc. Stud. Educ. Res., vol. 10, no. 2, pp. 323-343, 2019.

[16] H. B. Sutopo, Metode Penelitian Kualitatif Dasar Teori dan Penerapannya dalam Penelitian. Surakarta: UNS Press, 2006.

[17] J. P. Spradley, Metode Etnografi. Yogyakarta: Tiara Wacana, 2006.

[18] Nurochmana, M. R. Nababan, R. Santosa, and D. Kristina, "Sexist language in the little men novel: How male and female translators differ," Int. J. Innov. Creat. Chang., vol. 7, no. 8, pp. 308-330, 2019.

[19] L. Karyani, M. R. Nababan, and S. Marmanto, "Translation Analysis on Dayak Cultural Terms From Dayak Ngaju to Indonesian and English," Langkawi J. Assoc. Arab. English, vol. 6, no. 1, p. 41, 2020, doi: 10.31332/lkw.v6i1.1676.

[20] M. Nababan, "Aspek Genetik, Objektif, Dan Afektif Dalam Penelitian Penerjemahan," Linguistika, vol. 14, no. 26, pp. 15-23, 2007. 